\title{
Morphometric Analysis of Bhesra Kalan Micro-watershed using Remote Sensing and GIS Technique
}

\author{
Chandradeep Singh Rathore, Manjeet Singh, Mahesh Kothari and K.K. Yadav \\ Department of Soil and Water Engineering, College of Technology and Engineering \\ MPUAT, Udaipur-313 001, India \\ E-mail: chandradeepsinghrathore4@gmail.com
}

\begin{abstract}
The present study has been carried out to analyse morphometric characteristics of Bhesra Kalan micro-watershed of Udaipur (Rajasthan) by using remote sensing and GIS technique. The area of the micro-watershed is 1060 ha. Bhuvan DEM data of $30 \mathrm{~m}$ spatial resolution and topographical maps have been utilised to analyse stream network and determine geomorphological parameters (linear, areal and relief aspects) using in the GIS environment. The drainage network of the research area came out to be dendritic and the $4^{\text {th }}$ order stream observed as trunk order. The bifurcation ratio (3.24) indicates an undistorted drainage network and low structural disturbance in area. Form factor (0.227), elongation ratio (0.538) and circulatory ratio $(0.276)$ shows elongated shape of watershed. Drainage density $\left(2.626 \mathrm{~km} \mathrm{~km}^{-2}\right)$ implies permeable sub-surface material with sparse vegetation, mountainousrelief and coarse drainage. The value of constant of channel maintenance $\left(0.381 \mathrm{~km}^{2} \mathrm{~km}^{-1}\right)$ shows steep slope, high surface runoff and low permeability in the watershed. The low value of relief ratio (0.052) characterises less resistant rocks in area. The ruggedness number $(0.922)$ indicates the steep slope of the watershed. The findings of this study provide complete information about the watershed's geomorphological characteristics, which may help in watershed planning and management and explore groundwater potential.
\end{abstract}

Keywords: Morphometric characteristics, Micro-watershed, Remote sensing, GIS, Watershed planning

Morphometric analysis of streams is a vital factor for watershed characterisation (Chandniha and Kansal 2017). It is a quantitative method of defining drainage features and conveys key data about the watershed's topography, runoff, hydrogeological attributes of rock layers and geological conditions (Umrikar 2017). Geomorphic assessment of watershed is generally utilised for developing regional hydrological models to solve various watershed related problems when there is the unavailability of accessible database (Gajbhiye et al 2014). The viable management of watershed resources should be necessary objective for future strategic planning and management (Gautam and Awasthi 2020). The physical and hydrological conditions and morphometric parameters decide the reaction of a specific watershed to various hydrological processes and their behaviour (Bansode and Ajabe 2018). Geomorphic analysis of a watershed can be well understood by its drainage pattern, aerial and relief aspects, and slope of the region (Nag and Chakraborty 2003). The different geomorphological parameters including linear aspects (stream order, stream number, stream length, bifurcation ratio), areal aspects (form factor, basin shape factor, circulatory ratio, elongation ratio, drainage density, stream frequency) and relief aspects (maximum relief, relative relief, relief ratio, ruggedness number) need to be measured for morphometric analysis of watershed (Shaikh and Birajdar 2015). The geomorphological analysis of watershed using traditional methods is labour intensive, inconvenient and timeconsuming (Bera et al 2018). Remote sensing and GIS (Geographical Information System) are widely acknowledged as effective geospatial tools for creating drainage maps and determining the morphometric characteristics ofwatersheds (Singhand Urmila 2012). There are several researchers and scientists who performed morphometric analysis of watershed using remote sensing and GIS (Dhabale et al 2014, Asode et al 2016, Kumar et al 2017, Rai et al 2017, Savita et al 2017, Asfaw and Workineh 2019, Siddi Raju et al 2020 and Singh et al 2020). In the present research, an attempt is made to understand the morphometric characteristics of the Bhesra Kalan micro-watershed of Udaipur (Rajasthan) using remote sensing and GIS.

\section{MATERIAL AND METHODS}

Study area: Bhesra Kalan micro-water lies in Girwa Tehsil of Udaipur district of Rajasthan, India and covers 1060 ha area and lies between $24^{\circ} 37^{\prime} 33^{\prime \prime} \mathrm{N}$ to $24^{\circ} 39^{\prime} 48^{\prime \prime} \mathrm{N}$ latitude and $73^{\circ} 45^{\prime} 20^{\prime \prime} \mathrm{E}$ to $73^{\circ} 48^{\prime} 28^{\prime \prime}$ Elongitude. The watershed area covered under toposheet no. G43T14 (Fig. 1). The mean annual rainfall of the area is $662 \mathrm{~mm}$. The watershed falls in the agro-climatic zone- IVA of Rajasthan, i.e. Sub-humid 
southern plains of Aravalli hills. The study area comprises moderately dissected hills and valleys, low dissected hills and valleys, pediment pediplain complex, water bodies and others. The maximum and minimum elevations above sea level are $865 \mathrm{~m}$ and $511 \mathrm{~m}$, respectively.

Data and Software used: The data and software used to evaluate the geomorphological characteristics are represented in Table 1.

Morphometric analysis: Morphometric analysis is the systematic representation of watershed's geometry and its stream channel system to determine(I) Linear aspects of drainage network (stream order, stream number, bifurcation ratio, stream length, stream length ratio) (II) Areal aspects of watershed (form factor, basin shape factor, circulatory ratio, elongation ratio, drainage density, stream frequency, constant of channel maintenance) and (III) Relief aspects of

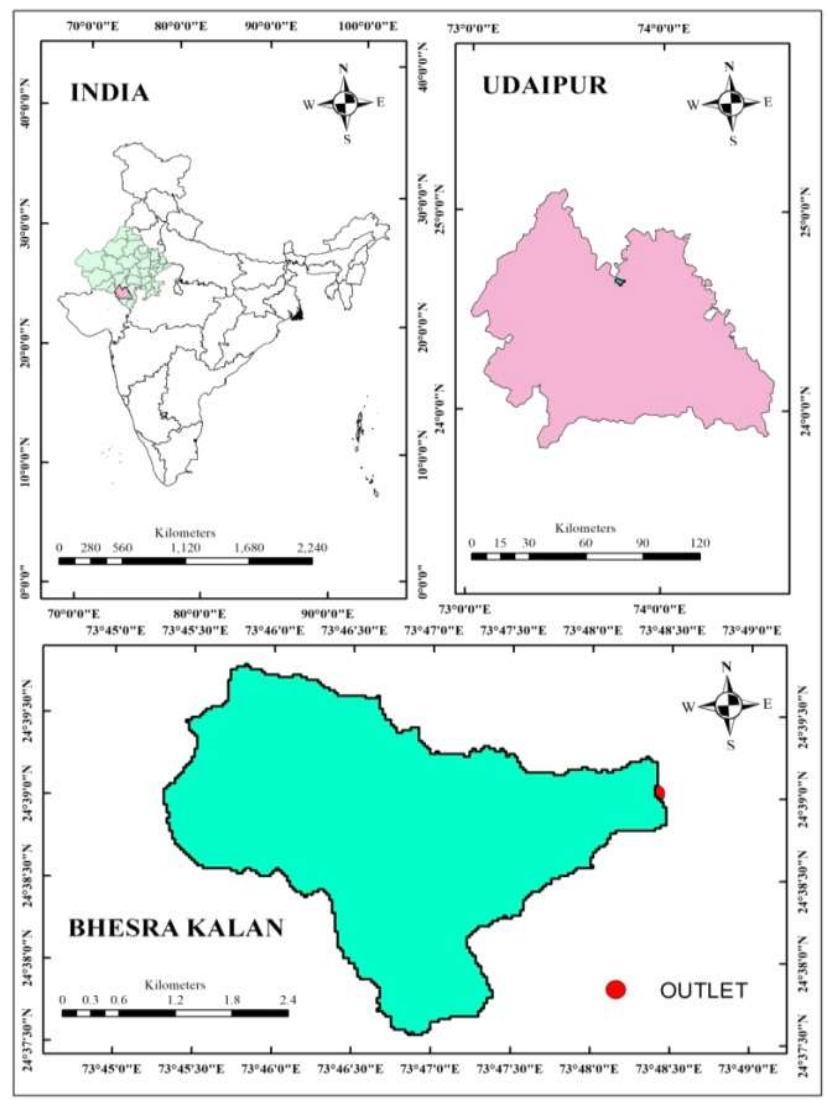

Fig. 1. Study area channel network (maximum relief, relative relief, relief ratio, ruggedness number). The geomorphological parameters can be determined using DEM data as a base layer and by applying suitable operations given in the ArcMap toolbar.

Determination geomorphological characteristics: The geomorphological parameters can be determined by using DEM data as a base layer and by applying suitable operations given in the ArcMap toolbar as tools > spatial analyst tools $>$ hydrology. The flowchart as shown in Figure 2 shows the procedures to obtain different morphometric aspects of watershed.

\section{DEM file $\longrightarrow$ GIS environment<smiles></smiles>$$
\text { Fill }
$$$$
\downarrow
$$ \\ Flow direction

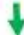 \\ Flow accumulation

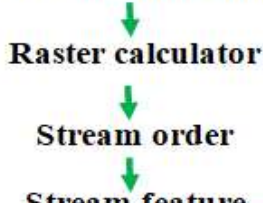 \\ Stream feature

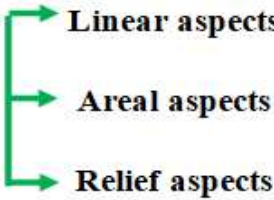

Fig. 2. Flowchart of procedure of determining geomorphological parameters

\section{RESULTS AND DISCUSSION}

After delineating the watershed, a drainage mapwas generated by applying operations from the hydrology tool available in the software toolbar (Fig. 3). The output drainage map of the study area hasdifferent stream orders (Fig. 4). Based on the measurements from the digitized drainage patterns and watershed boundary, the values of different geomorphological parameters of the watershed were calculated according to the formulas mentioned in (Table 2). The evaluated values of geomorphological characteristics are shown in Table 3.

Stream analysis: Stream analysis consists of grouping

Table 1. Software and data acquisition

\begin{tabular}{lcc}
\hline Software used & Use \\
\cline { 2 - 3 } ArcGIS 10.1 & To delineate and determine geomorphological characteristics of the area under research. \\
\cline { 2 - 3 } \begin{tabular}{lcc} 
Mata acquisition & Description & Source \\
\hline Remote sensing data & Toposheet (1:50,000 scale) & Survey of India (SOI) \\
bhuvan.nrsc.gov.in
\end{tabular} \\
\hline
\end{tabular}


stream segments in different orders ( $1^{\text {st }}$ to $4^{\text {th }}$ order), measuring stream lengths $(14.147 \mathrm{~km}, 7.293 \mathrm{~km}, 6.191 \mathrm{~km}$ and $0.212 \mathrm{~km})$, calculating cumulative stream length $(27.843$ $\mathrm{km})$ and calculating mean stream lengths $(0.488 \mathrm{~km}, 0.810$ $\mathrm{km}, 3.096 \mathrm{~km}$ and $0.212 \mathrm{~km}$ ).

Relationship between stream number/cumulative stream length and stream order/stream number: The correlation coefficient for the straight-line fit between the logarithm of stream number (ordinate) and stream order (abscissa) for the study area comes out to be 0.98 , which is quite satisfactory (Fig. 5). The same kind of graph was plotted between the logarithm of cumulative stream length

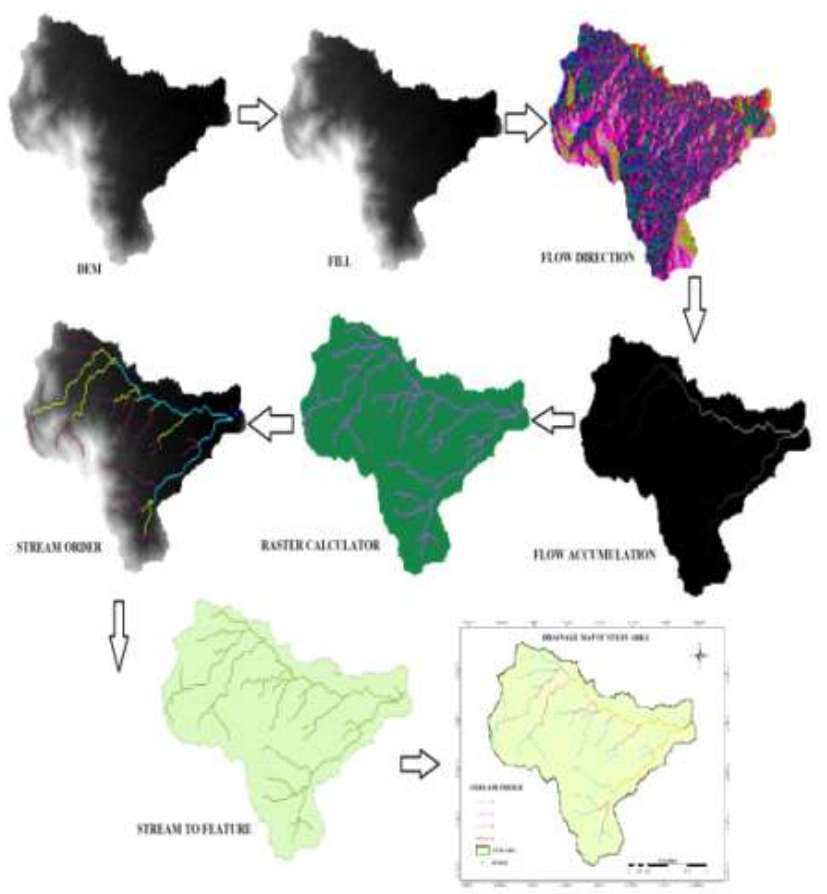

Fig. 3. Procedure of generating drainage map

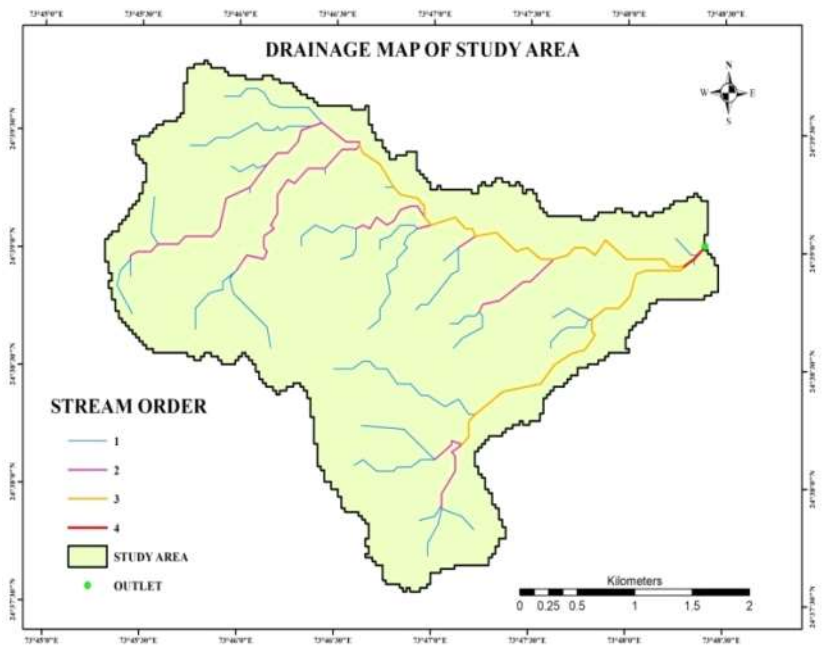

Fig. 4. Drainage map of the study area (ordinate) and stream order (abscissa) for verifying Horton's law (Fig. 6). It came out to be a straight line of fit with a satisfactory correlation coefficient of 0.86 , which was entirely satisfactory.

Linear aspects of drainage network: The linear aspects include stream order, stream number, stream length, bifurcation ratio and stream length ratio. The study revealed that the watershed is of $4^{\text {th }}$ order type with a dendrite drainage pattern (Singh 2005, Singh et al 2019). The stream numbers for the stream order $1^{\text {st }}, 2^{\text {nd }}, 3^{\text {rd }}$ and $4^{\text {th }}$ were $29,9,2$ and 1 , respectively and their corresponding stream length was

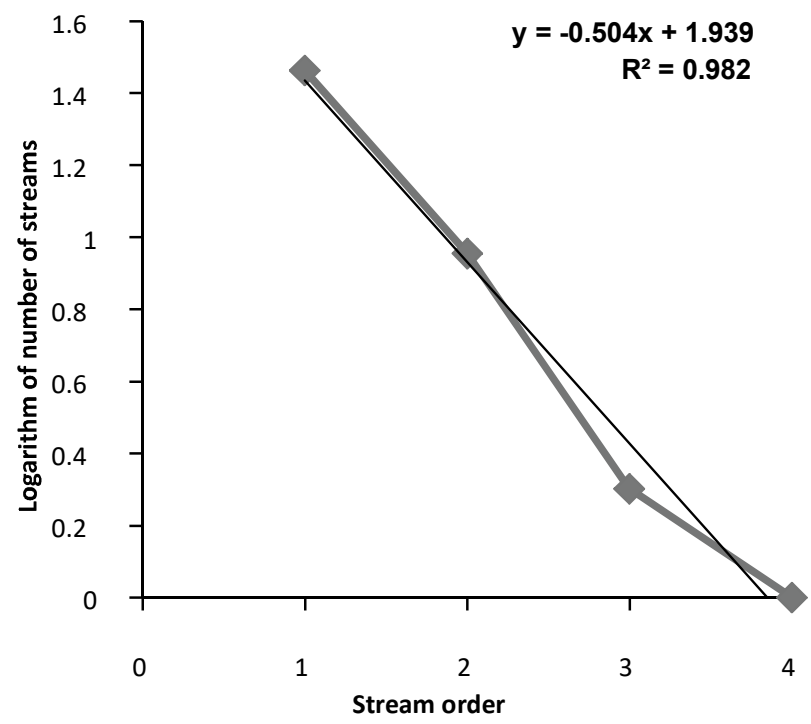

Fig. 5. Regression of logarithm of stream number and stream order

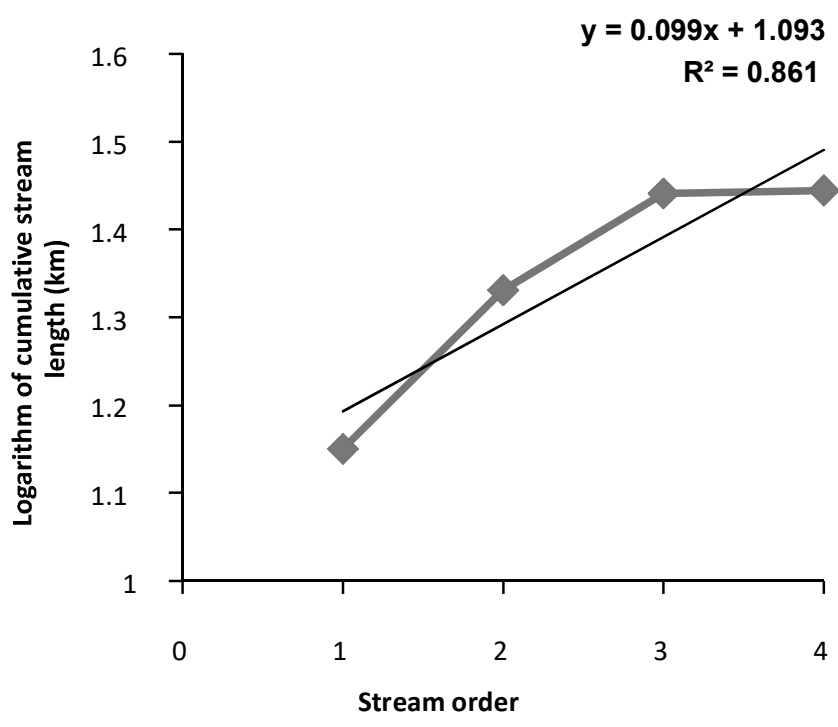

Fig. 6. Regression of logarithm of cumulative stream length and stream order 
$14.147,7.293,6.191$ and $0.212 \mathrm{~km}$, respectively. The bifurcation ratio $\left(R_{b}\right)$ for the Bhesra Kalan micro-watershed was in the range of 2.00 to 4.50 with an average of 3.24 and this low value shows that the watershed is less affected by the structural disturbance and the drainage pattern has not been distorted (Nag and Chakraborty 2003). The elongated basins have low $R_{b}$, while the circular basins have higher $R_{b}$ values, which show that the area under study is elongated. The average value of stream length ratio $\left(R_{L}\right)$ for the watershed evaluated as 1.850 . $R_{L}$ value between the successive stream orders of the watershed varies cause of differences in slope and topographic conditions (Singh 2005). The stream length ratio has an important relationship with the basin's surface flow discharge and erosional stage (Dahiphale 2014).

Areal aspects of watershed: The areal aspects include form factor, basin shape factor, circulatory ratio, elongation ratio, drainage density, stream frequency and constant of channel maintenance. The form factor value estimated as 0.227 indicates the shape of the watershed to be elongated and hence, a flat peak flow for a longer duration can be obtained in the watershed. Flood flow of elongated basins is much easier to manage in comparison to circular basins. The

Table 2. Calculation of geomorphological parameters.

\begin{tabular}{|c|c|c|}
\hline Morphometric parameter & Formula & Reference \\
\hline $\begin{array}{l}\text { Stream order and stream } \\
\text { number }\end{array}$ & Hierarchical order & Strahler (1964) \\
\hline Bifurcation ratio & $\mathrm{R}_{\mathrm{b}}=\mathrm{N}_{\mathrm{u}} / \mathrm{N}_{\mathrm{u}+1}$ & Schumm (1956) \\
\hline Mean stream length & $\bar{L}_{u}=\bar{L}_{u} / N_{u}$ & Strahler (1964) \\
\hline Stream length ratio & $R_{L}=\bar{L}_{u} / \bar{L}_{u}-1$ & Horton (1945) \\
\hline Form factor & $R_{f}=A / L_{b}^{2}$ & Horton (1945) \\
\hline Basin shape factor & $B_{s}=L_{b}^{2} / A$ & Horton (1945) \\
\hline Circulatory ratio & $R_{c}=4 \pi A / P^{2}$ & Miller (1953) \\
\hline Elongation ratio & $R_{e}=2 \sqrt{ }(A / \pi) / L_{b}$ & Schumm (1956) \\
\hline Drainage density & $D_{d}=\Sigma L_{u} / A$ & Horton (1932) \\
\hline Stream frequency & $F S=\Sigma N_{u} / A$ & Horton (1932) \\
\hline $\begin{array}{l}\text { Constant of channel } \\
\text { maintenance }\end{array}$ & $C=1 / D_{d}$ & Schumm (1956) \\
\hline Maximum watershed relief & $H=Z-Z$ & Strahler (1957) \\
\hline Relative $\mathrm{r}$ & $R_{R}=(H / P) * 100$ & Melton (1957) \\
\hline Relief ratio & $R_{r}=H / L_{b}$ & Schumm (1956) \\
\hline Ruggedness number & $R_{N}=H^{*} D_{d}$ & Strahler (1958) \\
\hline Time of concentration & $\mathrm{TC}=0.0195 \mathrm{~L}^{0.77} \mathrm{~S}^{-0.385}$ & \\
\hline
\end{tabular}

Where, $\mathrm{N}_{\mathrm{u}}=$ total no. of streams of order $\mathrm{u}, \mathrm{N}_{\mathrm{u}+1}=$ total number of streams of next higher order, $\mathrm{Lu}=$ length of stream of order $u, L u=$ mean stream length of order $\mathrm{u}, \mathrm{Lu}_{-1}=$ stream length of its next lower order, $A=$ area of watershed, $\mathrm{L}_{\mathrm{b}}=$ maximum basin length, $P=$ perimeter of watershed, $\Sigma L_{u}=$ total length of streams of all orders, $\sum N_{u}=$ total number of streams of all orders, $D_{d}=$ drainage density, $\mathrm{Z}=$ maximum watershed relief, $\mathrm{z}=$ minimum watershed relief, $\mathrm{H}=$ maximum watershed relief, $L=$ Length of channel reach, $S=$ Average slope of the channel reach
Table 3. Evaluated morphometric parameters of watershed Parameters Calculated value

Linear aspects

Area

$10.60 \mathrm{~km}^{2}$

Perimeter $21.95 \mathrm{~km}$

No. of stream order $\left(\mathrm{N}_{\mathrm{u}}\right)$

II 9

III

2

IV

1

Stream length $\left(L_{u}\right)$

I

$14.147 \mathrm{~km}$

II

$7.293 \mathrm{~km}$

III

$6.191 \mathrm{~km}$

IV

$0.212 \mathrm{~km}$

Bifurcation ratio $\left(\mathrm{R}_{\mathrm{b}}\right)$

$\mathrm{R}_{\mathrm{b} 1}$

$\mathrm{R}_{\mathrm{b} 2}$

4.50

$\mathrm{R}_{\mathrm{b} 3}$

2.00

Average

3.24

Average stream length

$0.488 \mathrm{~km}$

II

$0.810 \mathrm{~km}$

$3.096 \mathrm{~km}$

$0.212 \mathrm{~km}$

IV

1.661

$\mathrm{R}_{\mathrm{L} 1}$

1.661

$\mathrm{R}_{\mathrm{L} 2}$

$\mathrm{R}_{\mathrm{L} 3}$

0.068

Average

1.850

Areal aspects

Form factor $\left(\mathrm{R}_{\mathrm{f}}\right)$

Basin shape factor $\left(B_{s}\right)$

Circulatory ratio $\left(R_{c}\right)$

0.276

Elongation ratio $\left(R_{\mathrm{e}}\right)$

0.538

Drainage density $\left(D_{d}\right)$

$2.626 \mathrm{kmkm}^{-2}$

Stream frequency $\left(F_{s}\right)$

$3.867 \mathrm{~km}^{-2}$

Constant of channel maintenance (C)

$0.381 \mathrm{~km}^{2} \mathrm{~km}^{-1}$

Relief aspects

Maximum watershed relief $(\mathrm{H})$

$354 \mathrm{~m}$

Relative relief $\left(R_{R}\right)$

$1.612 \%$

Relief ratio $\left(R_{r}\right)$

0.052

Ruggedness number $\left(R_{N}\right)$

0.922

Time of concentration $\left(T_{c}\right)$

$63.32 \mathrm{~min}$ 
calculated value of basin shape factor for the study area was 4.397, showing the elongated watershed. The runoff discharge in an elongated basin is less efficient than a circular basin (Singh et al 2021).

The circulatory ratio $\left(R_{c}\right)$ value ranges from 0 to 1 , in which ratio value approaching 1 shows circular shape while value approaching 0 shows elongated watershed. The ratio is more influenced by the stream length and stream frequency than slope and drainage pattern. The value of Rc for the watershed came out to be 0.276 , which refers to the elongated shape of the watershed. The elongation ratio $\left(R_{e}\right)$, according to its values, is categorised as circular (0.9-1.0), oval (0.8-0.9), less elongated (0.5-0.7) and more elongated $(<0.5)$ by Strahler (1964). Strahler (1968) showed that the $R_{e}$ value when approaches to 1 indicated very low relief and when value is in the range of 0.5 to 0.8 , the area has strong relief and steep ground slope. The value of $R_{e}$ estimated as 0.538 enable the watershed to fall in a less elongated category with strong relief and steep slope.

Drainage density is a measure of how well or poorly a watershed is drained by stream channels. A low drainage density value indicates a relatively low density of streams and thus slow response (Srivalli and Singh 2017). The low drainage density $\left(D_{d}=2.626 \mathrm{kmkm}^{-2}\right)$ indicated that the area had permeable sub surface material with sparse vegetation, mountainous relief and coarse drainage (generally shows when value is less than 5.0). The value of stream frequency $\left(F_{\mathrm{s}}=3.867 \mathrm{~km}^{-1}\right)$ showed that the watershed had moderately resistant sub-surface material with low infiltration and moderate runoff. The value of constant of channel maintenance (C) came out to be $0.381 \mathrm{~km}^{2} \mathrm{~km}^{-1}$, which was quite low indicated area having steep slope, high surface runoff and low permeability.

Relief aspects of channel network: The relief aspects include maximum watershed relief, relief ratio, relative relief and ruggedness number. The maximum watershed relief was $354 \mathrm{~m}$. The relative relief is the ratio of maximum watershed relief to the perimeter of the watershed $(1.612$ $\%)$. The relief ratio is estimated as 0.052 . The low value of relief ratio is the characteristic feature of less resistant rocks of the area (Singh et al 2021). Ruggedness number $\left(R_{N}\right)$ is a dimensionless term indicating structural complexity of the terrain. It is a measure of surface unevenness (Selvan et al 2011, Singh et al 2018). The $R_{N}$ value of 0.922 for the study area show the steep slope of watershed. The time of concentration for the present study area computed as $63.32 \mathrm{~min}$, which shows some barriers in the flow path and runoff takes less time in reaching the outlet from the remotest point. The morphometric analysis of the study area shows that the watershed is of elongated shape with a steep slope.

\section{CONCLUSIONS:}

The morphometric analysis of Bhesra Kalan microwatershed was carried out to determine the watershed's linear, areal and relief aspects using Arc GIS 10.1 software. The drainage pattern of the watershed was observed as dendritic with $4^{\text {th }}$ order stream as trunk order. The linear relationship between the logarithm of stream number and stream order and logarithm of cumulative stream length and stream order verified their conformity with Horton's laws (1945) with a satisfactory correlation coefficient. The low value of the bifurcation ratio showed less structural disturbance and undistorted drainage pattern in the study area. The form factor value reflected a flat peak flow for longer duration in the watershed. A comparatively higher elongation ratio than the circulatory ratio implied elongated shape of the watershed. A low drainage density indicated that the area had permeable subsurface material with sparse vegetation. The maximum watershed relief was $354 \mathrm{~m}$. The relief ratio and ruggedness number showed the availability of less resistant rocks and steep slopes in the watershed. The present morphometric analysis of the study area indicates the elongated shape of the watershed with steep slopes. This study may assist the local policymakers and authorities for sustainable watershed management as well as augmenting the groundwater potential in the sub-humid to semi-arid regions.

\section{REFERENCES}

Asfaw D and Workineh G 2019. Quantitative analysis of morphometry on Ribb and Gumara watersheds: Implications for soil and water conservation. International Soil and Water Conservation Research 7(2): 150-157.

Asode AN, Sreenivasa A and Lakkundi TK 2016. Quantitative morphometric analysis in the hard rock Hirehalla Sub-basin, Bellary and Davanagere Districts, Karnataka, India using RS and GIS. Arabian Journal of Geosciences 9(5): 381.

Bansod RD and Ajabe GS 2018. Determination of geomorphological characteristics of Karpri-Kalu watershed using GIS Techniques. Journal of Pharmacognosy and Phytochemistry 7(1): 19401944

Bera A, Mukhopadhyay BP and Das D 2018. Morphometric analysis of Adula River Basin in Maharashtra, India using GIS and remote sensing techniques. Geo-spatial Data in Natural Resources 2(1): 13-35.

Chandniha SK and Kansal ML 2017. Prioritization of sub-watersheds based on morphometric analysis using geospatial technique in Piperiya Watershed, India. Applied Water Science 7(1): 329338.

Dahiphale P, Singh PK and Yadav KK 2014. Morphometric analysis of sub-basins in Jaisamand catchment using geographical information system. International Journal of Research in Engineering and Technology 2(6): 189-202.

Dhabale S, Singh PK and Singh RS 2014. Morphometric analysis of Chanavada micro-watershed using remote sensing and GIS. 
Journal of Soil and Water Conservation 13(1): 10-15.

Gajbhiye S, Mishra SK and Pandey A 2014. Prioritizing Erosionprone area through morphometric analysis an RS and GIS perspective. Applied Water Science 4(1): 51-61.

Gautam VK and Awasthi MK 2020. Evaluation of water resources demand and supply for the districts of Central Narmada Valley Zone. International Journal of Current Microbioogy and Applied Science 9(2): 3043-3050.

Kumar D, Singh PK, Kothari M, Singh RS and Yadav KK 2017. Application of remote sensing and GIS techniques in the analysis of morphometric characteristics of upper Berach River Basin, Rajasthan. International Journal of Agricultural Science and Research (IJASR) 7(5): 521-530.

Nag SK and Chakraborty S 2003. Influence of rock types and structures in the development of drainage network in hard rock area. Journal of the Indian Society of Remote Sensing 31(1): 2535.

Rai PK, Mohan K, Mishra S, Ahmad A and Mishra VN 2017. A GISbased approach in drainage morphometric analysis of Kanhar River Basin, India. Applied Water Science 7(1): 217-232.

Savita RS, Satishkumar U, Mittal HK, Singh PK and Yadav KK 2017. Analysis of hydrological inferences through morphometric analysis a remote sensing-GIS based study of Kanakanala Reservoir Subwatershed. International Journal of Agricultural Science and Research (IJASR) 7(6): 378-388.

Selvan MT, Ahmad S and Rashid SM 2011. Analysis of the Geomor phometric Parameters in High Altitude Glacierised Terrain Using Srtm Dem Data in Central Himalaya, India. ARPN Journal of Science and Technology 1(1): 22-27.

Shaikh M and Birajdar F 2015. Analysis of watershed characteristics using remote sensing and GIS techniques. International Journal of Innovative Research in Science 4(4): 1971-1976.
Siddi Raju R, Sudarsana Raju G and Rajasekhar M 2020 Morphometric analysis of Mandavi River Basin in Rayalaseema region of Andhra Pradesh (South India), using remote sensing and GIS. Journal of Indian Geophysical Union 24(1): 54-67.

Singh N, Jha M, Tignath S and Singh BN 2020. Morphometric analysis of a Badland affected portion of the Mandakini River Sub-watershed, Central India. Arabian Journal of Geosciences 13(1): 1-14

Singh D, Singh PK, Patil PR and Singh M 2019. Morphometric analysis of Mewado Ka Math Micro-Watershed using remote sensing and GIS. Green Farming 10: 354-359.

Singh $M$ and Urmila 2012. Assessment of soil and water conservation measures: A case study of the district Banswara, Rajasthan, India. Ecology, Environment and Conservation 18(04): 1045-1049.

Singh M 2005. Planning and designing of appropriate soil and water conservation measures in Kadmal watershed. Masters dissertation, MPUAT, Udaipur.

Singh M, Jat SC, Singh PK and Yadav KK 2021. Estimation of aquifer parameters in upper Berach River Basin area of Rajasthan, India. La Pensée 51(1): 547-552.

Singh PK, Dahiphale P, Yadav KK and Singh M 2018. Delineation of groundwater potential zones in Jaisamand basinof Udaipur district. In: Singh V, Yadav S, Yadava R (eds) Groundwater. Water Science and Technology Library, vol 76. Springer, Singapore. https://doi.org/10.1007/978-981-10-5789-2_1

Srivalli CR and Singh M 2017. Estimation of runoff for the watershed using SCS curve number method and GIS. International Journal of Agricultural Research 7: 83-88.

Umrikar BN 2017. Morphometric analysis of Andhale watershed, Taluka Mulshi, District Pune, India. Applied Water Science 7(5): 2231-2243. 